Педагогические основы организации самостоятельной работы студентов в вузе / Е. Л. Белкин. - Орел : Изд. Орлов. фил. Моск. ин-та приборостроения, 1989. - 65 с. 4. Бордовская Н. В. Педагогика / Н. В. Бордовская. - СПб. : Питер, 2001. - 304 с. 5. Васютин Ю. С. Рекомендации по методике организации учебных занятий: самостоятельная работа / Ю. С. Васютин. - М. : Изд-во РАГС, 1997. 33 с. 6. Гликман И. 3. Управление самостоятельной работой студентов (системное стимулирование) / И. 3. Гликман. - М. : Логос, 2002. - 24 с. 7. Дмитренко Т. А. Образовательные технологии в системе высшей школы / Т. А. Дмитренко // Педагогика. -2004. - № 2. - С. 54-59.

УДК [37.013.4:7]+7.012

Володимир Щербина, Дар'я Щербина

\title{
ФОРМУВАННЯ КОМПОЗИЦІЙНИХ УМІНЬ І НАВИЧОК У МАЙБУТНІХ УЧИТЕЛІВ ОБРАЗОТВОРЧОГО МИСТЕЦТВА ЯК ПОКАЗНИК ЇХНЬОЇ ПЕДАГОГІЧНОЇ МАЙСТЕРНОСТІ
}

Щербина В. Г., Щербина Д. В. Формування композиційних умінь і навичок у майбутніх учителів образотворчого мистецтва як показник їхньої педагогічної майстерності.

У статті розкрито психолого-педагогічні умови розвитку художньої творчості студентів художньо-графічного факультету, розглянуто систему вправ, яка сприятливо впливає на формування та розвиток композиційних умінь і навичок майбутніх учителів образотворчого мистецтва.

Ключові слова: композиційні уміння та навички, психолого-педагогічні умови, система вправ, учитель образотворчого мистецтва.

Щербина В. Г., Щербина Д. В. Формирования композиционных умений и навыков будущих учителей изобразительного искусства как показатель их педагогического мастерства.

В статье раскрываются психолого-педагогические условия развития художественного творчества студентов художественно-графического факультета, рассматривается система упражнений, которая благоприятно влияет на формирование и развитие композиционных умений и навыков будущих учителей изобразительного искусства.

Ключевые слова: композиционные умения и навыки, психолого-педагогические условия, система упражнений, учитель изобразительного искусства.

Shcherbina V. G., Shcherbyna D. V. Formation of compositional skills and habits of future teachers of fine arts as indicators of their pedagogical skills.

The article reveals psychologically-pedagogical conditions of an artistic creativity development of the students of Arts and Graphic Department; considers the system of exercises which favorably influences the formation and development of compositional skills and abilities of future teachers of fine arts.

Key words: compositional skills and habits, psychologically-pedagogical conditions, system of exercises, teachers of fine arts.

Сучасна тенденція розвитку України, іiі інтеграція в європейське і світове товариство висунула перед вітчизняною педагогічною наукою низку нових проблем, найважливіша 3 яких - реформування вищої школи. Одним із провідних принципів реформації вищої педагогічної школи $є$ відродження національної культури і мистецтва засобами навчально-виховної роботи. Формування у студентської молоді національної свідомості й гідності передбачає не тільки знання історії народу, але й володіння майбутнім учителем вітчизняними і світовими цінностями. Процеси, які відбуваються на сучасному рівні, розвиток культури й мистецтва, ставлять нові питання перед педагогічною теорією і практикою, а саме - якість підготовки майбутніх учителів у вищих навчальних закладах художнього напрямку (вчителів образотворчого мистецтва, декоративно-прикладного мистецтва, дизайну).

Визначено аксіоматичне положення: художньо-педагогічна діяльність майбутнього вчителя образотворчого мистецтва, рівень його кваліфікації визначається тим, наскільки він оволодів спеціальними художніми вміннями. Загальновідомо, що вміння - це складні комплексні дії, які формуються під час залучення студентів до творчої художної діяльності 
зокрема, під час виконання творчих завдань із композиції. При цьому фахівцями визнано, що композиційні вміння $є$ одними 3 визначних критеріїв у підготовці майбутніх учителів образотворчого мистецтва та його творчих педагогічних здібностей. Проблема формування композиційних умінь та навичок студентів у навчальному процесі i iï розширення безпосередньо пов'язується з удосконаленням навчально-виховного процесу загалом.

Цим питанням науковцями (педагогами, психологами, дидактами) завжди приділялась значна увага. Загальним проблемам удосконалення вищої професійної освіти присвячено наукові роботи С. Гончаренка, І. Зязюна, Н. Ничкало, М. Ярмаченко та інших.

У педагогічній літературі дуже широко розкриваються загальнодидактичні аспекти пізнавальних та творчих умінь (А. Алексюк, Ю. Бабанський, Є. Ільїн, В. Козаков, А. Кондратюк, В. Крутецький, І. Кулибаба, А. Левінов, М. Левітов, І. Лернер, В. Мазниченко, В. Онищук, В. Петров, П. Рудик, В. Семиченко, С. Сисоєва, А. Усова, І. С. Якиманська та інші). Психологічні аспекти досліджуваної проблеми розглядались у працях Б. Ананьєва, Д. Богоявленської, Л. Веккера, В. Гордона, В. Зинченко, О. Когана, Г. Костюка, О. Леонтьєва, С. Рубінштейна, О. Рудницької, О. Тихомирова, Н. Тализіної, Т. Яценко та інших.

Організація творчої діяльності студентів художньо-графічного факультету відіграє значну роль у процесі підготовки майбутніх фахівців. Проблему художньої творчості досліджували М. Волков, Л. Виготський, Є. Громов, Б. Мейлах, В. Моляко, Я. Пономарьов, В. Раппопорт, П. Якобсон та інші. Абсолютна більшість дослідників визнають, що процеси художньої творчості та композиційної діяльності загалом залежать від системи управління процесом розвитку композиційних умінь. Дослідження проблематики управління пізнавальною діяльністю студентів здійснювали В. Бондар, Ю. Конаржевський, В. Пикельна та інші.

Мета статті полягає в розгляді системи вправ, які сприятливо впливають на формування композиційних умінь та навичок майбутніх учителів образотворчого мистецтва.

Увагу до проблеми управління пізнавальною діяльністю студентів пов'язано 3 тим, що вдосконалення процесу навчання у вищий школі здійснюється нині на основі впровадження інтенсивних технологій навчання, активних методів організації пізнавальної діяльності майбутніх учителів (зокрема, учителів образотворчого мистецтва). Це насамперед стосується процесу навчання студентів композиції на художньо-графічному факультеті педагогічних вищих навчальних закладів.

У зв'язку з цим наше дослідження в подальшому спирається на фактори, що характеризують динаміку психічних і фізичних процесів, які сприяють формуванню та розвитку композиційних умінь і навичок, композиційного мислення в образотворчому мистецтві. Напрямок цієї роботи визначений у програмі конкретними практичними вправами, які сприяють оволодінню необхідним рівнем композиційної грамоти. Тому доцільно практичну частину, яку ми виклали в посібнику «Практична композиція», обгрунтувати деякими важливими положеннями більш загального порядку, а саме: що являє собою процес виконання вправи, яким закономірностям він підпорядковується, як належить тлумачити його з точки зору дидактики та основних принципів художньої педагогіки тощо.

У визначенні психолого-фізіологічних основ навчальних вправ з композиції ми виходимо 3 положень сучасної психології, даних фізіології про механізми психічної діяльності людини. Процес оволодіння студентами знаннями, формування у них умінь і навичок відбувається, як вважають науковці-психологи, під час утворення в корі великих півкуль головного мозку тимчасових нервових зв'язків. Формування цих зв'язків є складним процесом аналітикосинтетичної діяльності кори головного мозку. За частого й регулярного повторення процесів збудження й гальмування утворюється так званий динамічний стереотип, який є утворенням міцно закріплених рухомих систем або комплексів умовних рефлексів.

У навчальному процесі постійно відбувається утворення нових динамічних стереотипів, що позитивно впливають на успішне оволодіння студентами необхідними знаннями, вміннями та навичками.

Вироблення стереотипу становить важке для нервової системи завдання. Водночас підтримання вже виробленого не вимагає значного напруження коркової діяльності. І. Павлов підкреслював значення повторюваних вправ для закріплення утворюваних у корі головного мозку нервових зв'язків.

Проте навчальні композиційні вправи в художній педагогіці мають свою специфіку, яка нерідко призводить до деяких внутрішніх суперечностей. Особливо ці суперечності 
позначаються під час зіткнення свідомого контролю своїх дій з тенденцією до автоматичності або, як кажуть у художній практиці, до визначених композиційних прийомів і постійного користування ними як шаблонами у своїй композиційної діяльності.

Ця автоматизація зводиться до процесу, за якого помітно значною мірою нівелюється участь свідомості та довільної уваги до своєї роботи. У той же час навичку ніколи, і це особливо важливо в навчанні композиції, не слід доводити до того ступеня автоматичності, яка призводить до вимикання свідомого контролю й аналізу. Спостереження доводять, що в тих випадках, коли навичка переходить цю межу, виникає небезпека іiї «надуманості», і створена композиція втрачає свою оригінальність та виразність. Для того, щоб та чи та композиційна навичка могла бути доцільно використана під час розв'язання різних композиційних завдань, вона повинна володіти певною гнучкістю, «пластичністю», яка б перебувала в явному протистоянні з автоматизмом.

А. Риндін у своєму дослідженні розглядає формування навичок у процесі навчання живопису і знаходить, що цей процес повинен забезпечувати «достатню автоматичність, але зберігати при цьому необхідну пластичність» [4, с. 93]. Ці на перший погляд несумісні якості можуть бути сформованими тільки за дотримання певних умов. «Однією 3 них, - стверджує А. Риндін, $-\epsilon$ створення в процесі навчання живопису різноманітних ситуацій, які моделюють різноманітні варіанти дійсності. При досягненні певного рівня автоматичної навички від учня потрібне розв'язання завдань на межі, що відокремлює його від завченого прийому» [4, с. 94].

Практика композиційних вправ, спрямована на формування «пластичної навички», а точніше - «пластичного вміння», має значні переваги, оскільки надає змогу поширення цього досвіду на ті чи ті композиційні ситуації, для яких «пластичне вміння» спочатку і не було призначене. Сутність цього процесу полягає в тому, що розвиток особистих композиційних умінь та навичок за певних умов призводить до узагальнень. Завдяки цьому є можливим використання тієї або тієї навички не тільки за ії прямим призначенням, але й за аналогією. У тих випадках, коли викладачеві вдається стимулювати формування цих узагальнень на основі композиційної навички, у студента складаються й розвиваються певні композиційні здібності, тим самим сприяючи розвитку композиційного мислення й активації творчого процесу.

Визначення умов для утворення таких узагальнень залежить не тільки від природи композиційного бачення, але від методів його формування та розвитку. Сутність вправи як специфічного засобу навчального процесу полягає у навмисному створенні максимально сприятливих умов для розв'язання конкретного композиційного завдання.

Вправи дозволяють аналізувати об'єктивні закони композиції, формалізувати, виокремлювати із цілої низки композиційних засобів, які «працюють» у творі на ідею автора, один або кілька, вивчити, відпрацювати й інтерпретувати задля більш досконалого пізнання теорії і практики композиційної творчості, синтезувати теоретичні основи композиції і художньо-композиційної практики.

Міцне і свідоме засвоєння й інтенсивне накопичення практичного досвіду можливе лише в тому випадку, якщо всі ланки навчального процесу містять педагогічно ефективні вправи.

У загальній педагогіці результати узагальнення розглядаються як один 3 основних дидактичних принципів. Глибокі і міцні знання виникають лише в процесі свідомого їх засвоєння і залежать від послідовності їх викладання і закріплення на практиці. Однією 3 дидактичних закономірностей $\epsilon$ розвивальний характер навчання. Зв'язок i залежність психічного розвитку особистості від навчання була встановлена порівняно недавно. Відомо, що ще К. Ушинський був прихильником розвивального навчання, він говорив про пряму залежність розумового розвитку від змісту навчання.

Л. Виготський висловлював думку про те, що за наявності складних взаємовідносин між навчанням і розвитком, правильно організоване навчання завжди повинно випереджати розвиток, йти попереду нього і слугувати джерелом нового в розвитку. Він висунув положення про два рівня розвитку учня. Перший рівень - «рівень актуального розвитку» - це наявний рівень підготовленості, який характеризується тим, що учень може виконати завдання самостійно. Другий, більш високий рівень, Л. Виготський назвав «зоною найближчого розвитку», позначивши таким терміном те, що суб'єкт не може поки що зробити сам, але з чим він справиться з допомогою вчителя.

На думку Л. Виготського, результат, який отримує нині учень 3 допомогою інших (3 підказкою педагога), в подальшому буде досягнутий ним самостійно, тобто, те, що входило в 
зону «найближчого розвитку», у процесі навчання перейде на рівень «актуального розвитку» [1]. Отже, «зона найближчого розвитку» створюється навчанням, яке випереджає розвиток, причому кожен щабель навчання повинен спиратися на досягнутий рівень розвитку й цілеспрямовано підготовлювати наступні ступені.

Реалізація цього важливого дидактичного положення передбачена в запропонованій нами системі практичних вправ 3 композиції (навчальний посібник «Практична композиція») двома рівнями формування композиційних умінь та навичок у процесі навчання: «актуалізацією», тобто відновленням попереднього досвіду, та вдосконаленням композиційних умінь і навичок.

Величезну роль у реалізації цих дидактичних принципів відіграє методично правильна система практичних вправ, що відповідає певним психолого-педагогічним вимогам.

Система практичних вправ повинна бути побудована так, щоб можна було досягти формування композиційних умінь, самостійного використання цього досвіду в інших композиційних ситуаціях, застосування набутих знань, умінь і навичок у розв'язанні нових творчих завдань.

Іншими словами, вправи повинні формувати вміння i навички, яким притаманні рухливість, пластичність, пристосованість до різних композиційних ситуацій відповідно до поставленої мети та ідейного задуму.

Дослідження педагогів і психологів підтверджують, що найбільш досконалий шлях глибокого осмислення, вдосконалення та систематизації знань, формування необхідних умінь i навичок - це використання їх у практичній діяльності. Тому під час оцінювання ефективності системи вправ слід враховувати і відоме положення Л. Ітельсона про те, що «ефективне засвоєння понять і правил, закономірностей відбувається в процесі його застосування і що вправа - це перш за все свідома цілеспрямована діяльність навчання» [3, с. 327].

У зв'язку з цим у реалізації цього аспекту навчального процесу увага насамперед має бути акцентованою на раціональній свідомості.

Аналіз психолого-педагогічних джерел свідчить про нерозривний зв'язок емоційного й раціонального, чутливого і розумного та їх синтез, тобто думка відбивається емоціями. Почуття несе думку відповідно до процесу навчання: виконання практичної вправи 3 композиції значною мірою сполучено 3 осмисленням поставленого завдання. Процес осмислення, у свою чергу, припускає передбачення результатів роботи, установлення зв'язків і місця композиційних елементів, визначену організацію композиційної діяльності.

Орієнтація навчання та освоєння стадій творчого процесу під час виконання вправ підвищує мотивацію й розвиває самостійність композиційного мислення: постановка проблеми 3 об'єктивним прочитанням завдання, перша спроба як «запланована» помилка усуває страх помилкового кроку, стадія пошуку надає час для внутрішнього дозрівання i, нарешті, сам композиційний синтез, який виявляється на різних етапах - під час «створення» композиції, практичного втілення, у процесі навчання, - $€$ актом творчого самоствердження студента («особистісний момент»).

Слід зазначити, що в композиційній діяльності «помилка» як «неправильна дія» має зовсім інше значення, ніж те, як вона розуміється на пересічному рівні. Вона виконує переважно продуктивну функцію, особливо на початку розроблення ідейного задуму твору, і $є$ явищем закономірним. Зовсім іншу роль відіграє «помилка» на завершальному етапі розроблення композиції, тільки на цьому етапі відкривається «вища математика» композиції. Але і в цьому випадку художник повинен досягти максимальної користі та вигоди для себе, для своєї роботи. 3 цього приводу змістовно висловлювався відомий художник С. Далі: «У будь-якій помилці майже завжди $€$ щось від Бога. Так що не поспішай скоріше ії виправити. Навпаки, намагайся осягнути іiі розумом, дійти до самої суті. І тобі відкриється її таємний зміст» [2, с. 75].

У процесі формування композиційного бачення, професійно-педагогічної майстерності спрямованість самого процесу виконання вправи, стадій іï послідовності переноситься на результат. Водночас не можна процес формування композиційних умінь і навичок зводити до простої сенсорно-моторної координації. Наявність цієї координації звільняє свідомість від усіх дій, надає можливість більш глибокого розуміння і пізнання композиційних закономірностей.

Мірою формування композиційних умінь і навичок, прийом із мети стає засобом дій, а функція свідомості набуває більш широкого характеру. Чим складніші композиційні уміння та навички, тим більше часу потрібно на їх формування та розвиток, тим більшу роль відіграє у 
вправі координаційний механізм. У процесі формування композиційних умінь і навичок і їх якісної реорганізації, інтелектуальна діяльність студента, його свідомість набуває особливо великого значення. Залежно від того, наскільки відбивається у свідомості процес утворення і формування композиційного уміння і способу подолання труднощів, змінюється і темп їх формування, їх якісна характеристика.

Отже, проведене дослідження не вичерпує всієї проблеми композиційної підготовки майбутніх фахівців і потребує подальшого вдосконалення сучасних методик і технологій у композиційній підготовці фахівців мистецтва та вчителів образотворчого мистецтва. Залишаються актуальними питання, які вимагають відповідної уваги з боку педагогічної науки i практики. Це такі напрямки, як: дослідження єдності процесу формування композиційних умінь, навичок і загальних художніх умінь 3 використанням моделей управління; розвиток композиційного мислення студентів у процесі пізнавальної діяльності; формування й розвиток цілісного образного уявлення.

\section{Література}

1. Выготский Л. С. Психология искусства / Л. С. Выготский. - М. : Педагогика, 1987. - 361 с. 2. Дали С. Дневник одного гения / С. Дали. - М. : Искусство, 1991. - 75 с. 3. Ительсон Л. Б. Лекции по современным проблемам обучения / Л. Б. Ительсон. - Владимир, 1972. - 327 с. 4. Рындин А. С. Световая и цветовая среда в живописи / А. С. Рындин // Вопросы теории и методики преподавания художественно-графических дисциплин. - Краснодар: КГПИ, 1975.- 237 с. 5. Пикельная В. С. Теоретические основы управления: Школоведческий аспект / В. С. Пикельная. - М.: Высшая школа, 1990. - 175 с. 6. Щербина В. Г. Практична композиція: [навч. посіб. для студ. вищих навч. закладів] / В. Г. Щербина. - Кривий Ріг, 2012 - 180 с. 